\title{
POČÁTKY ČESKÉ KRITIKY UMĚLECKÝCH PŘEKLADŮ Z ANGLIČTINY V DEVATENÁCTÉM STOLETÍ: OD RECENZÍ K TEORII
}

\author{
BOHUSLAV MÁNEK
}

\begin{abstract}
The paper outlines and discusses the beginnings, character and development of Czech criticism of translations of English literature in the nineteenth century. It does so in the wider context of debates concerning the role of translated literature in the development of a national culture. The development from short reviews to more elaborated critical statements is traced primarily through the critical reception of Shakespeare's plays and Lord Byron's poetry. The works of these two authors continued to be translated over the course of the whole century, were considered to be of great importance, and had a powerful impact on Czech culture. Reviews and critiques of translated fiction are mentioned only briefly, as they appeared later and their evaluation would require a separate study. Czech translation criticism developed under specific conditions due to the social and political situation of the Czech nation: after a period of gradual decline of the standard Czech language following the Thirty Years' War, the Czech language was gradually regaining the status of a language of literature and science. The last two decades of the $18^{\text {th }}$ century and first half of the $19^{\text {th }}$ century are thus called the period of the Czech National Revival. In its first decades, all translations as well as original Czech writings were well received in short reviews of theatre performances and books. Subsequently, as the century progressed, Czech translation criticism gradually developed to produce more elaborated theoretical statements, focusing on two principal questions: the suitability of translated authors and works for the recovering culture; and the quality of the translations themselves. With few exceptions, the first short critical comments concerning translations were published in the 1830s in reviews of theatre performances, more extended and more profound reviews and critiques started to be published in the 1850s. Some translators, e.g. J. Malý, P. Sobotka and J. Durdík were also reviewers, and some of their reviews and critiques can be considered to be the first steps towards the twentieth century development of Czech Translation Studies in the writings of Otokar Fisher, Jiří Levý and others.
\end{abstract}

Key words: translation criticism, 19th century Czech literature, Czech National Revival, Shakespeare, Byron 
Vznik, charakter a postupný rozvoj kritiky českých překlado̊ z angličtiny v průběhu devatenáctého století, na což se tato práce omezuje, lze dobře sledovat na recepci překladů Shakespearových dramat a poezie Lorda Byrona, což byli v devatenáctém století dva nejvíce a průběžně překládaní autoři. Hodnocení překladů anglické beletrie a jiné prózy vyžaduje zvláštní studii, zde se omezíme jen na nezbytné zmínky. Od konce osmnáctého století se po období postupného vytlačení češtiny z oblasti státní správy a vyšších společenských i kulturních sfér jako důsledku porážky českých aspirací ve třicetileté válce postupně obnovuje spisovná čeština rovněž jako jazyk vyspělých literárních forem. První původní česká tvorba a první nečetné překlady se objevují od osmdesátých let, ale značná část těchto textů, často velmi zjednodušených, byla překládána $\mathrm{z}$ dobových německých verzí nebo s jejich pomocí, např. Krameriův výtah ze spisů Johna Smithe (1798), robinzonády aj. K nejranějším překladům patří především Shakespearova dramata volně překládaná z rovněž volnějších německých verzí. Již roku 1782 jako knížky lidového čtení vyšly zjednodušené prozaické verze Macbetha (Makbet vi̊dce šottského vojska) a Benátského kupce (Kupec z Venedyku) bez zmínky o Shakespearovi, pod jeho jménem pak roku 1786 Makbet, prozaický zjednodušený překlad v podání Karla Hynka Tháma (1763-1816), který byl v té době i provozován podobně jako Král Lír a jeho nevděčné dcery v překladu Prokopa Šedivého (1764-1810) roku 1792. Knižně ještě vyšel roku 1823 volný prozaický překlad Omylové, tj. Komedie omyli̊ v překladu Bolemíra Izborského, což byl pseudonym Antonína Marka (1785-1877), ale nebyl nikdy nastudován. Ostatní Shakespearovy hry provozované v tomto raném obrozeneckém období, o nichž jsou zmínky, se nedochovaly. (Drábek 2012: zde kritická vydání těchto raných textů; dále Mánek 2005, 2015) O těchto překladech nemáme $\mathrm{v}$ češtině delší zásadní dobové recenze. Nicméně drobné hodnocení dvou výše zmíněných knížek lidového čtení najdeme v němčině v přehledu dobové literární produkce od Josefa Dobrovského (1753-1829) v Litterarisches Magazin von Böhmen und Mähren. „Český překladatel přetavil Kupce benátského v román. [...] Zdá se, že tato práce je určena pro obecný lid a také pro měštanské dcery v českých městech. Překladatel slibuje také více podobných prací." (Dobrovský [1786] 1953: 154) O Thámově překladu Makbeta až v roce 1852 Ferdinand Břetislav Mikovec (1826-1862) stručně usoudil, že „ostatně však nad jiné překlady divadelní oné doby patrně vynikal správností a plynností“ (Mikovec 1852: 46).

První kritická hodnocení překladů z angličtiny se objevují od třicátých let, kdy dochází ke kvantitativnímu i kvalitativnímu rozvoji překladatelství z angličtiny. Zprvu se nacházejí pouze jako krátké zmínky v rámci referátů o divadelních představeních, v nichž jsou především hodnoceny výkony herců a hereček, režie a výprava, později se odděleně hodnotí i tištěné překlady. Rozvíjí se samozřejmě i překladatelství $\mathrm{z}$ antických, slovanských, románských a germánských jazyků a jejich kritická hodnocení a objevují se i první stručné názory na úlohu překladové literatury v české kultuře. Bohaté zdroje v tomto ohledu shromáždil Jiří Levý ve své průkopnické antologii doprovázející jeho studii České teorie prekladu (1957). Levý zde sleduje především postupný vývoj teoretických zásad pro překladatelskou praxi a její hodnocení a většinou stranou ponechává drobné recenze a konkrétní připomínky k úrovni překladu. Pavel Drábek v rozsáhlé monografii České pokusy o Shakespeara (2012) podrobně zachytil a zhodnotil vývoj české recepce Shakespearových dramat a málo dostupné rukopisy a tisky vydal v př́loze své studie. 
Překlady a recepci Byronova díla v devatenáctém století sledovala monografie První české překlady Byronovy poezie (Mánek 1991).

$\mathrm{V}$ roce $1834 \mathrm{v}$ rámci úvahy o soudobém divadle básník a literární kritik Josef Jaroslav Chmelenský (1800-1839) klade v souvislosti s dobovou divadelní produkcí tuto otázku: „Co se má nejvíce překládati? Tato otázka se často namítá, a tu ten radí to, onen ono. Já myslím, že se zde ničeho předpisovati nedá, at každý to, seč jest, pracuje. Nám schází skoro všecko, aspoň nemáme ničeho nazbyt. Cokoliv spisovatele a nakladatele najde, musí nám býti vítáno, dobré semeno vzejde a rozšírí se, špatné se samo udusí. Kdožby se ve věci tak důležité opovažoval hráti na Katona? Kdožby svůj vkus a svoje subjektivní mínění za pravidlo všeobecné vydávati se osměloval? Spisovatele vede čest, aby všemožně dobré předměty volil, a nakladatele zisk a čest. [...] Nechtějme také samá mistrná přeložení, vímet', že v žádném národu samých mistrů není. [...] Překládání dobrých věcí jest nejen nesnadná, alebrž velice chvalitebná věc“ (Chmelenský 1834: 175).

Přihlédneme-li při hledání vhodné ukázky ilustrující dobový přístup k širšímu kontextu, než jsou překlady z angličtiny, o něco později Chmelenský r. 1835 chválí Tylův volný překlad jednoaktové hry Die Domestikenstreiche od I. F. Castelliho nazvaný Oba šelmy a postihuje dva tehdejší překladatelské přístupy: domestikující adaptaci (srov. Mánek 2013) a tendenci k co nejvěrnějšímu překladu hodnotných děl, která v pozdějším vývoji převážila. Chválí, že veselohra je „svobodně přeložená a veršem rýmovaným, jenž originálu schází, ozdobená. Takových přeložení tím více chváliti dlužno, poněvadž na originál neupomínají, ano se jím samým býti zdají. Při věcech klasických žádáme ovšem všemožně věrného přeložení, při jiných bud’me panům překladatelům vděčni, jestli jenom svobodným přeložením originál zušlechtují, jakož se tuto dálo.“ Úsilí o přirozené jazykové vyjádření originálu hodnotí i u překladu Kotzebueovy hry Epigram od Jana Vávry: „Přeložení jest zcela nenucené a české. Zvláště se mu dobře podařily mnohé hříčky ve slovech, kterými originál, a vůbec dramatická díla pana z Kotzebue oplývají" (Chmelenský 1835: $15,16) .{ }^{1}$ Chmelenský sledoval české divadlo a literaturu v celé šíri a je považován za zakladatele naší soustavné divadelní a literární kritiky (Štěpánek 1965).

Ve třicátých letech jsou inscenovány již překlady z anglických originálů. Prvním z nich byl Král Lear, aneb Nevděčnost dětenská (inscenován 1835, tiskem Shakespeare 1966 a Drábek 2012: 357-490; o překladech a inscenacích Mánek 2005) ve veršovaném překladu J. K. Tyla. Chmelenský přivítal „mistrovský kus mistra největšího v přeložení pěkném“ a zároveň formuloval již náročnější požadavky: „Původní kus dá se dobře posouditi, třeba referent knihu před sebou neměl, nebo zde má kritika pole širší; přeložení však jen tenkráte spravedlivě se oceniti dá, když je řádku za řádkou srovnávati mohu s originálem. Až potud tedy já své delší posouzení odkládám, až se již ted' přiznati smím, že jsem hojnost pěkných věcí seznal i z prvního pozorování" (Chmelenský 1836: 7).

Dalšími veršovanými překlady byly inscenace Makbetha (1838, uveden 20. 1. 1839) a Benátského kupce (uveden 8. 12. 1839, oba tiskem Drábek 2012) v překladech Josefa Jiřího Kolára (1812-1896). Jsou rovněž vřele vítány, nicméně na ně začínají být kladena přísnější měřítka (údaje o premiérách a publikacích viz Drábek 2012 a Mánek 2015). (Václav) Klement Püner (1811 - po 1860) ve svém referátě o Makbethovi uvedl: „Velmi

1 Ignaz Franz Castelli (1781-1862), rakouský dramatik; August von Kotzebue (1761-1819), německý dramatik a básník. 
chvalitebné jesti toto počínání, jakož i překlad sám zdařilým nazvati by se mohl, kdyby řeč dosti plynná byla, jak dalece se o ní z představení souditi může; mnohé periody příliš dlouhé pro nedosti důsledné sestavení slov byly těžce k srozumění. Možná, že toho i nezdařilá deklamací herců některých vina, - možná ale také, že řeč takto uspořádaná snadně se deklamovati nedá“ (Püner 1839: 32). Jakub Malý (1811-1885), který se stal jedním $\mathrm{z}$ nejplodnějších překladatelů $\mathrm{v}$ devatenáctém století, podobně jako jiní recenzenti v této a pozdější době, se věnuje především hodnocení nastudování a výkonu herců, nicméně zde v jeho hodnocení Benátského kupce najdeme i stručné hodnocení k překladu: „Překlad, až na některé maličkosti, jest velmi dobrý, a nemůžeme se zdržeti, vyjevit p. Kolárovi žádost svou, by nás více překlady z Shakespeara obdařil, nepochybujíce, že čím pilněji o to pracovati bude, tím dokonalejší se stane jeho práce“ (Malý 1839: 400).

Rozsáhlejší kritické reakce vyvolaly překlady ze čtyřicátých a padesátých let. Někteří tehdejší př̀kladatelé byli zároveň recenzenty prací svých kolegů. Hlavními kritiky v té době byli historik a básník Jan Erazim Vocel (1803-1871), básník a překladatel Václav Bolemír Nebeský (1818-1882), dramatik a básník Ferdinand Břetislav Mikovec, filolog a překladatel Václav Zelený (1825-1875), překladatel Jakub Malý a především v šedesátých letech Jan Neruda (1834-1891). Častým rysem těchto hodnocení je srovnávání se staršími či soudobými německými verzemi posuzovaných děl.

První tištěný veršovaný překlad Othella (1843, hrán 29. 5. 1842) od Jakuba Malého vyvolal první větší polemiku o překladech. Klement Püner (1842: 212) se v hodnocení premiéry kriticky vyjádřil o schopnostech většiny herců, ale překlad nehodnotil. Recenze knižního vydání překladu od Václava Nebeského byla vcelku kladná, nicméně po úvodních pasážích charakterizujících hru a její recepci v Německu obsahovala také několik výtek, zkritizovala i některá drobná nepochopení v textu: „Pan Malý osvědčil svou obratnost a výtečnost našeho jazyka, kterouž on vpraviti se může ve formy neobvyklé. První překlad německý Wielandův zůstal daleko za prvním českým. Pan Malý nepřekládal sice tak věrně, jako nyní Němci Shakespeara překládají, za to se ale tento český převod snadněji čte, a později dá se i tomu vyhověti, až se jen více sil o převedení pokusí. Schváliti ale nemůžeme, že p. Malý na některých místech obtížím se vyhnul, ano někde je i vynechal. Také se nám zdá, že je básnická barvitost někde setřena, zvláště na místech bouřlivých a tklivých, kde šepot a hrom se střídají. [...] Verš p. Malého je až prŕliš svobodný - ba pouhé počítání sylab. Bylo by k přání, abychme jednou, co se veršování týče, již k nějakému sjednocení přišli. Máme př́zvuk, časoměru a - anarchii!“ (Nebeský 1843: 13).

$\mathrm{V}$ reakci na recenzi Malý většinu Nebeského výtek odmítl. Zdůraznil věrnost a čtivost svého překladu, protože podle jeho mínění soudobí němečtí překladatelé „ducha písmenou, jako zajíce klackem, zabíjeji“. Vynechávky zdůvodnil nepřeložitelností a tím, že některá pasáž se „pro svou špinavost a necudnost jen surovým vkusem onoho věku omluviti se dá. A co se toho týká, tuším, že žijeme v století příliš vzdělaném, než abychom dopouštěti se měli onoho snižujícího modlářství Tibetanů, kteří lejno svého Dalai Lamy za drahý klenot a vzácný talisman považují. “ Odmítl i další konkrétní výtky a naopak vytkl Nebeskému př́lišnou nekritičnost vưči německým překladatelům. Nepravidelnost verše uznal, ale hájil ji odkazem na nepravidelnost verše originálu a snahou o plynulost (Malý 1843: 27-28). Později Nebeský publikoval spíše než recenze českých překladů delší shakespearovské studie, $\mathrm{v}$ nichž analyzoval hry a jejich literární, biografické a historické 
kontexty a v nichž kvality českého překladu nehodnotil, např́iklad u příležitosti českého překladu Richarda III. r. 1855 (Nebeský 1851-1852, 1855).

O něco později roku 1843 podrobně recenzoval Malého překlad Jan Erazim Vocel. Lze říci, že zde provedl detailnější hodnocení shodující se s principy Nebeského kritiky. Nacházíme zde čtyři typické tematické okruhy dobových recenzí: zdůraznění velikosti a důležitosti Shakespearova díla a chválu pokusů o jeho uvedení pro české publikum, porovnání s německým překladatelstvím, menší výtky týkající se překladu (nepochopení správného významu některých pasáží, zjednodušení, vynechávky, nevhodný styl) a diskuse týkající se údajné vulgárnosti některých pasáží, jak ilustrují tyto citáty: „Budiž nám vítán plod tento literární, seznamující Čechoslovany s nejvýtečnějším geniem dramatickým, oslavujícím národ britanský. [...] [K]aždému vzdělanému národu tř̌eba, do skladu znamenitých plodů literatury své klásti překlady Shakespeara. [...] Zřretelná, a lehce plynoucí řeč jesti nemalou p. překladatele zásluhou, začež mu tím více povděčni býti musíme, povážíme-li, jak nesnadno jest i Němcům, ješto jsou spřízněni jazykem svým s Angličany, Shakespeara věrně a plynně překládati. Toho však litujeme, že p. M. se nevyhýbal přísněji výrazům hrubým, an jich řeč naše česká ve slohu vyšším tak trpělivě nikoli nesnáší, jako jazyk germanský; ano zdá se, že si p. M. ve výrazech takovýchto liboval, užívaje je i tam, kdež jich ani v originálu anglickém není; n. př. hned v prvním výstupu, prvního jednání překládá p. M. abhor me, necht̉ čertův jsem, a hned na to: despice me, necht šelmou sluji. Vůbec mohlo by se říci, že sloh p. Malého není tak nadchnutý duchem básnickým, jakožby ku předmětu takovému náleželo. Na některých místech pan překladatel si úlohu př́liš usnadnil, tak překládá lowing his own pride and purposes, svou hlavu má; my downright violence and storm of fortunes, změna v mých okolnostech (!).“ Dále například překladu Desdemoniny písně (4.3) vytýká př́lišnou blízkost slovanskému folklóru. Podobně jako Nebeského posudek odráží situaci vývoje novočeského verše: „O způsobu veršování v díle přeloženém posud nevhodno mluviti, an otázka, dotýkající se české prosodie, dosavád rozhodnuta není." Celkový závěr je přese všechny výtky kladný: „Nicméně může větší díl překladu toho slouti zdařilým a věrným, svědectví dávaje o důmyslu a vzorném slohu překladatele českého." (Vocel 1843: 293, 294-295, 297).

Od třicátých let s rozšiřujícím se čtenářským publikem vzrůstá i produkce jak původní české, tak přeložené beletrie včetně překladů $\mathrm{z}$ angličtiny. Její hodnocení by si vyžádalo speciální studii, kde by bylo nutné vzhledem ke skrytým překladům vzít v úvahu i tehdejší stav literatury, na který výstižně po letech vzpomíná Karolina Světlá (1830-1899): „Seznámivši se s literaturou českou, vřele jsem ocenila její básníky, nedostižné tlumočníky národní poesie: Čelakovského a Erbena, okouzlujícího Máchu, nadšeného Vocela, jemnocitného Jablonského atd., ale prosaisté čeští docházeli u mne mnohem menší obliby. Shledávala jsem v nich tolik reminiscencí na spisovatele jinojazyčné, a to nikoli jen spisovatele prvního řádu, jako např. Auerbacha, podle něhož jsou v jistých pracích celé výjevy nejen padělány, nýbrž i celé stránky opsány, ale i na hvězdy druhé a třetí velikosti, jako např. Van der Veldeho, Blumenhagena, Tromlitze atd., kteříž jsou našemu pokolení asi již zcela neznámí, že jsem se skutečně někdy doopravdy při čtení rozhorlila. Ted' ovšem soudím jinak a uznávám, kdyby oni spisovatelé se nebyli obětovali, podávajíce nám, jak leckterý z nich, zejména poctivý Filípek mi svěřil, práce svoje se srdcem stísněným, neb byli si svých nedostatků a snad i plagiátů dobře vědomi, zdaž by bylo mohlo u nás vůbec cosi beletristického vycházeti? Museli chtějíce nechtějíce vytvořiti literaturu, 
o niž v první řadě se jednalo, a v druhé řadě teprve o hodnotu plodů jejich. Doopravdy mne poutali jen Tyl a Němcovác (Světlá 1959, 240-241). ${ }^{2}$

K beletristickým překladům se zprvu kritika prŕliš nevyjadřovala, ale jejich zvýšená produkce zřejmě způsobila volání po přísnějším kritickém výběru autorů a děl a úrovni překladů. Svědectví o tom najdeme ve stati Stručný přehled nejnovějších beletristických překladů z roku 1852, ve které František Ladislav Vorlíček (1828-1865, podepsán Fr. L. V-k.), učitel a překladatel z polštiny, na základě svého hodnocení (i negativního) několika próz kritiku požaduje: „Literatura bez kritiky podobá se člověku bez svědomitosti, jest nedospělá, co plodí dobrého, plodí maně, co vydává chatrného, vydává bez viny - slovem jest bez prŕíčitky. ${ }^{3}$ [...] I táži se předně, proč překládáme?" (Vorlíček 1852: 2) Četnost kritických projevů hodnotících prózu pak od padesátých let značně stoupá.

Od druhé poloviny padesátých let do začátku let sedmdesátých začínají postupně vycházet jednotlivé Shakespearovy hry v nových překladech v rámci projektu Matice české při Museu království Českého, na kterém se nejvýrazněji podíleli František Doucha (1810-1884), který již roku 1847 vydal svůj překlad Romea a Julie, a Jakub Malý. Na jednotlivé překlady reagovaly rozsáhlé posudky v dobovém tisku. Ty již vytyčovaly náročné požadavky na uměleckou a jazykovou úroveň, upozorňovaly na chyby, porovnávaly překlady s originály a později i s novými překlady J. V. Sládka (1845-1912) vydávanými pod záštitou České akademie věd a umění. Příkladem může být recenze Václava Zeleného na Douchovy překlady Romea a Julie (1847) a Richarda III. (1855). Náročné úvodní scéně z Romea a Julie např́klad vytýká: „Pan D. odvážil se překladu celého místa, ovšem neštastně, jakož jinak býti nemohlo. Vedle nedostatkův pocházejících nutně z věci samé jsou však tu i některé jiné, jimiž vyhnouti se nebylo nemožné. Tak by místo: ,Samson ... a proto se ženské jakožto slabší stvoření držívají vždy hradby (are ever thrust to the wall)‘ mělo by zníti: ,a proto se ženské ... vždy tisknou ke zdi.' Vưbec v této rozmluvě slova hradba chybně užito místo zdi." Zelený pak vypočítává půl tuctu chyb z prvního dějství a mnoho dalších z překladu Richarda III., například: „Na str. 1 praví Gloster: $\mathrm{V}$ paninské hopká bystře komnatě při laškování loutny zvučivé (to the lascivious pleasing of a lute.) Z celého smyslu vysvítá, že tu nemůže býti míněno nevinné laškování, nýbrž zvuky k vilnosti budící. Jest to stránka, na kterouž Gloster u svého bratra neustále naráží. Hlavním kritériem je Zelenému celková umělecká kvalita díla: „Milerádi bychom odpustili překladatelům Shakespearovým celé kopy pokleskův, jen když by celé dílo províval vánek básnický. Naopak může býti překlad prost všelikých chyb, pečlivý a věrný, a přes to všecko nezáživný a prkenný“ (Zelený 1855: 138, 141, 138). Je překvapivé, že ani Ferdinand Břetislav Mikovec, ani Jan Neruda, nejvýraznější divadelní kritici padesátých a šedesátých let, se k jazykovým a stylistickým kvalitám překladů ve svých početných referátech a obecných úvahách prakticky nevyslovili.

Vzájemné konfrontace verzí různých překladatelů mezi sebou a originálem jsou dalším krokem k ustavení kritiky překladu jako specifické disciplíny. Jako příklad poslouží recenze Sládkova překladu Zkrocení zlé ženy v Národních listech r. 1896 od dobového významného literárního kritika Jana Voborníka (1854-1946), porovnávající některá místa z př̀ekladů Malého, Kolára a Sládka: „Tak zase Shakespeare v novém rouše českém!

2 Berthold Auerbach (1812-1882), Carl Franz van der Velde (1779-1824), Wilhelm Blumenhagen (1781-1839), August von Tromlitz (1773-1839) - němečtí spisovatelé.

3 Tj. hodnocení, sebehodnocení. 
Shakespeare! Přes nehasnoucí slunce slávy své jest přece dnes jaksi pozastřen mlhami modernosti. Jak jiné to byly časy, když vycházely ty rozmile nazelenalé sešity z nákladu Matičního s překladem tu Douchovým, tu Kolarovým atd. A to už jsme zastali přece jen papírového Shakespeara. Lepší doba, kdy se hrdinové jeho skvěli na českém jevišti a ve slavnostním průvodě Umělecké besedy, ta už minula i nám. A dnes? Co je Shakespeare dnešnímu pokolení? Jeho kothurn už jaksi nechutná.“ Chválí sice „uhlazenost [Sládkova] verše“ a „jemnější vkus opravdu básnický“, nicméně soudí, že „[p]athetický ,Makbeth“ se mu, dle mého zdání, lépe povedl, než ,Zkrocení zlé ženy. Zvláště pěkně jsou vypracovány tragické samomluvy a vášnivé scény činu. "Vyjádřil se i kriticky k některým Sládkovým veršům $\mathrm{z}$ hlediska možnosti jejich přednesu herci a přes některé výtky co do přesnosti vcelku kladně zhodnotil i starší Kolárův překlad (Voborník 1896: 4).

Navzdory vcelku kladnému hodnocení se Sládek proti některým Voborníkovým výtkám ohradil, především proti jeho hodnocení významu Shakespearova díla pro současnost: „Shakespeare přečká asi i toto pokolení a mnohá jiná až do věkưv!“ Vyjádřil se také ke Kolárovu překladu: „Pan profesor neporovnává můj překlad s originálem, ale s překladem Kolarovým. [...] Náš „Starý pán“ se svým Makbethem a svými ostatními Shakespearovskými překlady! - Smeknout! - V jasném úderu, v hlubokém zvuku, v barvě slova, síle výrazu, - at to vůbec někdo po Starém pánu udělá! Ale Starý pán byl Starý pán! - byl Kolar a on si mohl dovolit hoditi do čarodějného kotle Shakespearova leckterý ten $\mathrm{z}$,chcíplé mrchy zpodek pupku; trus z mločí píce; statou lunu', samé věci, o kterých se ani Čarodějnicím Shakespearovým nezdálo. Nevytýkám mu to, nikoliv; jsem jist, že Shakespeare v Hadu nebo v Elysiu našemu Starému pánu řekl na uvítanou: Dobrá, starý brachu! Ale víš, - Josefe, Jiří, někde v tom tak nejsem já, William Shakespeare.' - Starý pán se ušklíbnul: ,Williame Shakespeare! Ale jsem v tom já, Josef, Jiří Kolar!’ A šli spolu dále jako dobří kamarádi“ (Sládek 1895-1896: 216).

Kritická recepce Byronovy poezie měla odlišné rysy. Zatímco Shakespeare byl od počátku přijímán kladně (výše uvedené Voborníkovy výhrady jsou výjimkou), v Byronově př́ípadě byla kritická recepce zaměřena převážně ideově. Zprvu negativně hodnotila jeho „rozervanost“ a ve spojitosti s recepcí Máchova díla a romantismu vůbec odmítala jejich vhodnost pro obrozující se národ. Z hlediska konkrétní kritiky textů přeložených básní se diskuse většinou týkaly realizace složitějších veršových útvarů (Mánek 1991). První překlady Byronových básní jsou rovněž volnější, ale na rozdíl od překladů Shakespeara vycházejí většinou přímo $z$ anglických originálů. Od dvacátých a třicátých let je do češtiny uvádějí Karel Ferdinad Dräxler (1806-1879), Jan Nepomuk Lhota (1811-1890, pod pseudonymem J. L. Květoslav Bystřický), Jakub Malý a Josef Jiří Kolár. Obdobně jako u raných překladů ze Shakespeara je Lhotův překlad básnické povídky Mazeppa zkrácený a v próze (Mánek 1991: 56-58).

Od padesátých let do první světové války pak následují desítky překladů Byronovy lyriky, epiky a lyrickodramatických útvarů. Od názorů na škodlivost jeho recepce (např. v rámci známých kritik Máchova Máje) pozorujeme vývoj k jeho rehabilitaci, ke kladnému přijetí a nakonec k zařazení mezi klasiky. Velkou úlohu zde sehrála knižně vydaná řada přednášek filozofa a kritika Josefa Durdíka O poezii a povaze lorda Byrona (1870), v jejímž rámci přeložil i několik ukázek. „Žádná literatura nemůže se bez překladu Byrona slušně obejít, jako bez překladu Shakespeara“ (Durdík 1870: 187). Durdík měl přesné představy o překladu i jako teoretik. „Obsah básnický“ se v jeho pojetí skládal „z látky 
a z vnitřní formy“, kterou chápal jako poměr myšlenek, který je nutno překladem vystihnout. Při realizaci „zevnější formy“ žádá zachování metra a délky veršů, u složitějších strofických útvarů dovoluje jistou volnost u rýmu. Příkladem je jeho řešení Spenserovy strofy v Childe Haroldovy pouti: „zachoval jsem totiž rytmus i délku verše i celek sloky, ale rým musel padnout. [...] Ponechal jsem jej jakožto upomínku na tuto okrasu veršův toliko ve dvou posledních řádkách sloky, abych spád a zakončení její patrněji naznačil“ (Durdík 1870: 86, 90). Praktickou kritikou jeho přístupu se stal překlad celé básně Spenserovou strofou od Elišky Krásnohorské (1847-1926) (1871: 31, 1890). Nicméně Durdíkovy překlady byly oceněny, například básník a překladatel Otokar Mokrý (1851-1899) chválí: „Byronův ,Kain` v překladu Dra. Durdíka, jemuž se podařilo plnou měrou dostihnouti naskrze zvučným a bezvadným veršem formalních kras velkolepého originalu“ (Mokrý 1876: 764).

Nejvýraznějším a nejvýznamnějším shrnutím zkušeností překladatelů a kritiků překladu a krokem směrem k ustavení moderních českých studií v oblasti kritiky a teorie překladu jsou v devatenáctém století stati Jakuba Malého O překládání klasikư, se zvláštním žretelem na Shakespeara a Dva překlady Shakespearovy tragédie, Romea a Julie“ (Malý 1854, 1870). Ke vzniku dějin českého překladatelství jako disciplíny pak přispěl etnograf, spisovatel a překladatel Primus Sobotka (1841-1925), který ve své stati O prrekladech $v$ novočeské literatuře podal rozsáhlý přehled o nejvýznamnějších překladech od počátku devatenáctého století, provedl první pokus o jejich periodizaci a zhodnotil jejich přínos, včetně překladů $\mathrm{z}$ angličtiny: „Na konec nelze nám neučiniti kratičké poznámky o tom, kterak v nejnovější době překlady básníkův moderních, najmě anglických a francouzských, přispěly k vybroušení jazyka českého“ (Sobotka 1877: 317-318). Koncem století jsou již kritické recenze překladů na odborné úrovni srovnatelné s ostatními rozvinutými evropskými literaturami. K dalšímu rozvoji bádání o překladu počátkem dvacátého století výrazně přispěl literární vědec, básník a překladatel Otokar Fischer (1883-1938) (Čermák 1984, Fischer 2015), který přeložil Makbetha (1916), publikoval studii o jeho české recepci (Fischer [1915/16, 1919], 2015: 223-238) a věnoval značnou část svého kritického díla také př̀kladům. Přehled postupného vývoje demonstrovaného na kritických projevech hodnotících překlady ze Shakespeara a Byrona ukazuje postupný vývoj od stručných hodnocení kvality přeložených textů nepodložených systematickou teorií k formulování obecněji platných zásad pro hodnocení překladu v rozsáhlých teoreticky hlouběji fundovaných studiích. V průběhu dvacátého století pak úroveň českého překladatelství a kritiky a teorie překladu dále rostla a v díle Jiř́ho Levého získala mezinárodní ohlas.

\section{POUŽITÁ LITERATURA}

Byron, Lord (1890) Childe-Haroldova pout', přel. Eliška Krásnohorská. Praha: F. Šimáček.

Čermák, Josef (1984) 'Otokar Fischer', in Etapy českého uměleckého překladu, Praha: Sdružení českých překladatelů: 1-21.

Dobrovský, Josef ([1786] 1953) Výbor z díla, přel. Benjamin Jedlička, Praha: SNKLHU.

Drábek, Pavel (2012) České pokusy o Shakespeara, Brno: Větrné mlýny.

Durdík, Josef (1870) O poesii a povaze lorda Byrona. Praha: J. S. Skrejšovský. 
Fischer, Otokar (2015) Literární studie a stati I., II., Praha: Univerzita Karlova.

Chmelenský, Josef Krasoslav (1834) 'Něco o divadle ve Lvově a o překládání z cizích jazyků', Česká včela 1(22): 174-176.

Chmelenský, Josef Krasoslav (1835) 'Divadlo', Česká včela 2(2): 15-16.

Chmelenský, Josef Krasoslav (1836) 'Divadlo', Česká včela 3(1): 6-8.

Krásnohorská, Eliška, přel. (1871) '[Lord Byron:] Oceánu', Květy 6(4): 31.

Krásnohorská, Eliška (1890) přel. Childe Haroldova pout', Praha: F. Šimáček.

Levý, Jiř́ (1957) České teorie překladu, Praha: SNKLHU.

Malý, Jakub (1839) 'Divadlo', Česká včela 6(100): 400.

Malý, Jakub (1843) 'Na dorozuměnou', Květy 10, Noviny z oboru literatury, umění a věd. (Př́loha ku Květům) VII: 27-28.

Malý, Jakub (1854) 'O překládání klasiků, se zvláštním zřetelem na Shakespeara’, Časopis Musea království Českého 28(4): 501-524.

Malý, Jakub ([1870], 1876) 'Dva překlady Shakespearovy tragédie „Romea a Julie“', Pokrok 2, přetištěno in Výbor drobných prací Jakuba Malého, sv. II., Praha: I. L. Kober, 246-259.

Mánek, Bohuslav (1991) První české překlady Byronovy poezie, Acta Universitatis Carolinae, Philologica, Monographia CXII - 1990, Praha: Karolinum.

Mánek, Bohuslav (2005) 'Král Lear v českých překladech a na českém jevišti', in William Shakespeare. Král Lear - King Lear, přel. Martin Hilský, Brno: Atlantis, 345-371.

Mánek, Bohuslav (2013) 'Translation as Support of National Identity Formation with Focus on English Literature in the Czech National Revival', in Ivona Mišterová a Eva Skopečková (ed.) A Search for Identity, Plzeň: Západočeská univerzita v Plzni, 6-15.

Mánek, Bohuslav (2015) 'Macbeth v českých překladech a na českém jevišti' in William Shakespeare. Macbeth - Macbeth, přel. Martin Hilský, Brno: Atlantis, 271-315.

Mikovec, Ferdinand Břetislav (1852) ‘České divadlo’, Lumír 2(2): 45-47.

Mokrý, Otokar (1876) 'Hlídka literární. Poesie světová. Nákladem tiskárny Dra. Edvarda Grégra’, Časopis Musea království Českého 50(4): 764-766.

Nebeský, Václav (1843) 'Othello mouřenín Benátský. Truchlohra od Shakespeare, přeložená od Jak. Bud. Malého. V Praze 1843', Noviny z oboru literatury, umění a věd, Květy 10(Příloha ku Květưm IV): 13-14.

Nebeský, Václav (1851-1852) 'William Shakespeare', Časopis českého Museum 25(3): 122-141; 26(1): 152-168, (2): 147-159.

Nebeský, Václav (1855) ‘Dramatická díla Williama Shakespeara. Nákladem Musea království Českého I. Život a smrt krále Richarda III. Přeložil Fr. Doucha. V Praze 1855', Časopis Musea království Českého 29(1): 118-123.

Püner, (Václav) Klement (1839) 'Divadlo', Česká včela 6(8): 32.

Püner, (Václav) Klement (1842) 'Divadlo', Česká včela 9(53): 212.

Shakespeare, William (1966) 'Král Lear, aneb Nevděčnost dětenská, Literární archiv 1, Praha: Památník národního písemnictví, 10-52.

Sládek, Josef Václav (1895-1896) 'Feuilleton', Lumír 24(18): 216.

Sobotka, Primus (1877) 'O překladech v novočeské literatuře’, Osvěta 7(4): 304-318.

Světlá, Karolina (1959) Z literárního soukromí. Vzpomínky. Paměti. Literární dokumenty, Praha: SNKLHU, 240-241.

Štěpánek Vladimír (1965) ‘Josef Krasoslav Chmelenský (K počátkům naší literární kritiky)’ in František Buriánek (ed.) Z dějin české literární kritiky, Praha: NPL, 9-84.

Voborník, Jan (Vbk) (1896) 'Z literatury', Národní listy 36(72): 4 (ranní vydání).

Vocel, Jan Erazim (1843) 'Překlady klasiků všech národů a časů, věd a umění. Číslo III. Othello, mauřenín benátský. Truchlohra v pateru jednání od W. Shakespeara, přeložená od Jak. Bud. Malého’, Časopis českého Museum 17(2): 293-297.

Vorlíček, František Ladislav (Fr. L. V-k.) (1852) 'Stručný přehled nejnovějších beletristických překladů.' Pražské noviny 1852(2): 2-3; (3): 1-2; (4): 2; (5): 1; (6): 1-2.

Zelený, Václav (1855) 'Williama Shakspeara Romeo a Julie. Přeložil Fr. D. V Praze 1847. Spisů musejních číslo XXVII. Dramatická díla Williama Shakespeara. Nákladem Musea království Českého. I. Život a smrt krále Richarda III. Přeložil Fr. Doucha. V Praze 1855', Obzor 1855(1): 135-144. 


\section{RESUMÉ}

Les débuts de la critique tchèque des traductions de l'anglais au XIXe siècle à partir des comptes rendus critiques vers la théorie.

Après la Guerre de Trente ans, la langue tchèque a été reléguée à l’arrière-plan dans les hautes couches de la société, aussi bien dans l'administration que dans la vie culturelle en général. Vers la fin du XVIIIe siècle le tchèque est peu à peu renouvelé comme langue des formes littéraires évoluées. Cette période entre le dernier quart du XVIIIe siècle et la moitié du XIXe siècle est appelée le Renouveau national tchèque. Il s'agissait essentiellement de reconquérir l'identité du peuple tchèque et de ressusciter sa langue. La nouvelle production littéraire tchèque et les premières traductions peu nombreuses apparaissent à partir des années quatre-vingt; ces textes ont été traduits de manière plutôt simplifiée d'après les versions allemandes de l'époque. Notre étude porte sur la naissance, le caractère et lépanouissement de la critique des traductions de l'anglais vers le tchèque pendant le XIXe siècle. Cette évolution est présentée par les textes de l'époque, par les réflexions sur la littérature ou les comptes rendus critiques des traductions publiées dont la source est la critique des traductions des pièces de Shakespeare et de la poésie de lord Byron. Les premiers comptes rendus critiques des traductions de l'anglais apparaissent dans les années trente. C’est à cette époque-là quon observe le développement de la traduction à partir des langues antiques, slaves, romanes et germaniques. Les premières réflexions sur le rôle de la littérature concernant la technique de la traduction visent à deux questions principales: le choix des oeuvres, des auteurs et la réalisation concrète des textes. Au cours de la première étape du Renouveau national on a accepté, avec une admiration peu critique, cette littérature mais dans la seconde moitié du siècle les exigences de qualité des traductions ont été déjà plus sévères. Certains traducteurs étaient en même temps critiques, par. ex. J. Malý, P. Sobotka et J. Durdík. Leurs comptes rendus critiques comportent déjà des réflexions théoriques plus profondes, de sorte qu'on peut y repérer des approches translatologiques. A partir de brèves critiques, on constate l'évolution aboutissant à la formulation des principes généraux dans les travaux fondés sur une base théorique. Pendant le 20e siècle le niveau des traductions tchèques, de la critique et de la théorie de la traduction n'a cessé de monter surtout dans les études de Otokar Fischer et, enfin, dans l'oeuvre de Jiř́ Levý, ce niveau a connu un retentissement international.

prof. PhDr. Bohuslav Mánek, CSc. Katedra anglického jazyka a literatury, Pedagogická fakulta, Univerzita Hradec Králové bohuslav.manek@uhk.cz 